\title{
REVIEW \\ Application of Acidified Sodium Chlorite Prewashing Treatment to Improve the Food Hygiene of Lightly Fermented Vegetables
}

\author{
Yasuhiro INATSU*, Md. Latiful BARI and Shinichi KAWAMOTO \\ Food Hygiene Laboratory, National Food Research Institute \\ (Tsukuba, Ibaraki 305-8642, JAPAN)
}

\begin{abstract}
Sanitation efficacy of prewashing with acidified sodium chlorite (ASC) for the production of lightly fermented Chinese cabbage was evaluated. The treatment of raw cut Chinese cabbage with ASC for 15 min significantly reduced the level of pathogens without causing apparent changes in color. The population of natural microflora on the leaves was reduced by about $2.0 \log \mathrm{CFU} / \mathrm{g}$ just after washing with ASC, which is significantly better than what was achieved with a control distilled water wash (P $\leq 0.05$ ). In a control experiment, viable aerobic bacteria increased gradually when incubated at $10^{\circ} \mathrm{C}$, however, ASC washed cut Chinese cabbage maintained a lower microbial level. The treatment of cut Chinese cabbage with ASC reduced the population of artificially inoculated Escherichia coli $\mathrm{O} 157: \mathrm{H} 7$, Salmonella Enteritidis, Staphylococcus aureus, and Listeria monocytogenes by $2.4 \log$ CFU/g. The sanitation efficacy of ASC was $1.6 \log \mathrm{CFU} / \mathrm{g}$ higher than that of distilled water washing. The viable cell counts of all pathogenic bacteria tested remained constant during 8 days of storage at $10^{\circ} \mathrm{C}$ for both washing treatments with the exception of $L$. monocytogenes. In the case of L. monocytogenes, the viable cell counts after ASC washing treatment increased gradually with time. No significant difference in color, odor, taste, and texture change in raw leaves or fermented ones was observed with an ASC wash compared to a distilled water wash. These results suggested that prewashing with ASC could control the bacterial growth in lightly fermented Chinese cabbage without changing its quality.
\end{abstract}

Disciplines: Food

Additional key words: bacterial control, food poisoning

\section{Introduction}

Fermented vegetables are an integral part of the diet of people in many countries ${ }^{50}$. The organic acids or other metabolites produced by lactic acid bacteria during the fermentation process give the raw vegetables a desirable taste, flavor or texture ${ }^{10}$. In addition, fermentation enriches food substances biologically with vitamins, protein, essential amino acids and fatty acids ${ }^{12}$. Lactic acid fermentation of cabbage and other vegetables is a common method for preserving fresh vegetables. However, the most important role of lactic acid fermentation is the preservation of perishable vegetables and fish in sanitary and safe conditions. The organic acids or bacteriocins produced by a long period of fermentation may suppress the growth of pathogenic or spoilage bacteria ${ }^{1,31,41}$. The microflora of fermented vegetables is influenced by their salt concentration ${ }^{44,45,50}$. In high salt concentrations, the growth of bacteria tends to be repressed by low water activity and high ionic activity in general. In suitable concentrations, salt will suppress the growth of undesirable bacteria without affecting that of lactic acid bacteria (LAB).

Traditionally in Japan, a rather higher (over 5\%) salt concentration has been adapted for long-term fermentation. However, lightly salted and/or fermented vegetables are becoming more preferred with consumers because a trend toward convenient yet healthy foods is seen as part of a modern lifestyle. In such a situation, several food borne outbreaks with lightly-fermented (salted) vegetables have been reported recently in Japan ${ }^{2,21,42,43}$. In August to September 2001, a disseminated outbreak of Escherichia coli $\mathrm{O} 157: \mathrm{H} 7$ in the Kanto area of Japan occurred and

*Corresponding author: e-mail inatu@affrc.go.jp

Received 5 December 2005; accepted 19 June 2006. 
the epidemiological investigation suggested that locally made kimchi was one of the incriminated food items. This raised special concern about kimchi borne transmission of E. coli $\mathrm{O} 157: \mathrm{H} 7$.

The raw vegetables used for the production of fermented vegetables could be contaminated in the farm and serve as a vehicle of pathogenic bacteria ${ }^{6,37}$. It is difficult to reduce viable cells of pathogenic bacteria once fermented vegetables become contaminated during their production. According to our inoculation study concerning the fate of pathogenic bacteria in laboratory prepared Japanese styled Kimchi ${ }^{21}$, Staphylococcus aureus decreased rapidly from its initial inoculum level to a minimum detectable level within 12 days and L. monocytogenes took 20 days to reach a similar level (Fig. 1). There was little increase in the population of E. coli $\mathrm{O} 157: \mathrm{H} 7$ and Salmonella Enteritidis observed over the first 4 days and they decreased slightly over 8 days and/or remained constant throughout the incubation periods, where as a decrease in the population of S. aureus and L. monocytogenes was observed over time. These results indicate that pathogenic bacteria could survive if there is any contamination in the raw materials and/or at any stage of the fermentation process.

If the raw vegetables, used for the production of lightly-fermented vegetables, were contaminated with pathogenic bacteria at any stage of pre- or post-harvest production and/or during marketing, this could contribute to the potential risk of food poisoning associated with the products. This paper deals with the effectiveness of acidified sodium chlorite (ASC) on reducing pathogenic bacteria during prewashing of raw leafy vegetables for lightly fermented vegetable production.

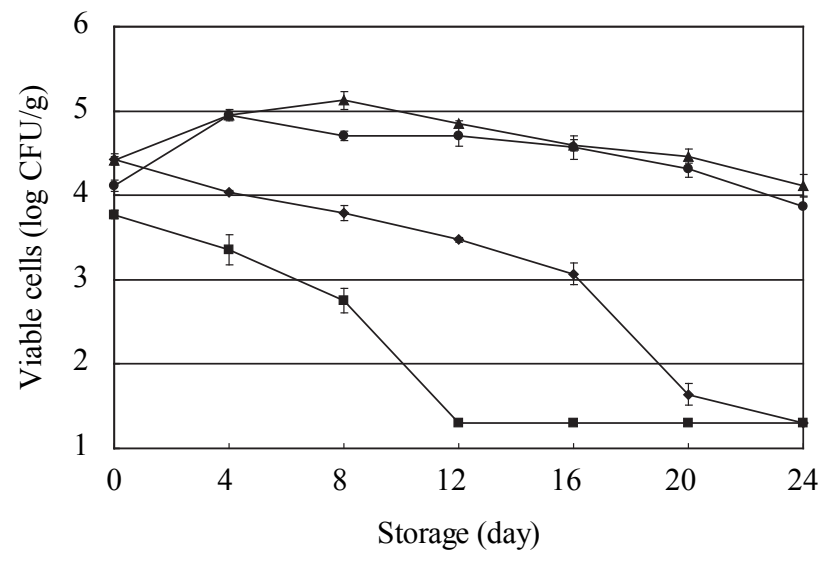

Fig. 1. Survival of inoculated strains of Escherichia coli 0157:H7 (○), Salmonella Enteritidis (A), Staphylococcus aureus ( $\square$ ), and Listeria monocytogenes $(\diamond)$, in laboratory prepared Japanese style kimchi that were kept at $10^{\circ} \mathrm{C}$ for 24 days $(n=4)$

\section{Sanitation of the attached bacteria on the surface of raw vegetables by ASC}

Normally, leafy vegetables harbor 2-7 $\log \mathrm{CFU} / \mathrm{g}$ of mesophilic bacteria including coliform or spoilage bacteria such as Pseudomonas as their normal microflora ${ }^{5,7,14,38}$ and LAB on leaves play an important role for fermentation. Overgrowth of bacteria increases turbidity of clean dipping sauce and causes inadequate quality for lightly fermented (or salted) vegetables ${ }^{25,35,40}$. In addition, vegetables can act as a vector in transporting pathogenic bacteria from a farm. A lot of reports revealed that vegetables pose a risk of transmitting pathogenic bacteria from farms ${ }^{6,37}$. Although washing produce with tap water may remove some soil and other debris, it cannot be relied upon to remove microorganisms completely and may result in cross-contamination of food preparation surfaces, utensils and other food items ${ }^{7-9}$. To reduce the risk of food poisoning caused by lightly fermented vegetables, effective sanitizing of the raw produce may be required. Washing raw produce with sodium-chlorinated water $(\mathrm{NaClO})$ is the most commonly used method to remove pathogens from surfaces of vegetables ${ }^{11}$. Many experimental studies have been performed to evaluate the effectiveness of sodium chlorinated water, acidic electrolyzed water or other sanitizers for sanitation of pathogenic bacteria on the surface of vegetables ${ }^{4,27-30,32,49}$. Active hypochlorite is believed to lose its effectiveness by reacting with nitrogen containing compounds in foods, resulting in halogenated organic compounds ${ }^{7,19}$. Concern over the carcinogenicity and toxicity of these compounds, particularly trihalomethanes, has prompted consideration of alternative disinfectants ${ }^{55}$.

Several investigations revealed that chlorine dioxide is a disinfectant equal to or more effective than chlorine ${ }^{33}$. This compound has been reported to inactivate bacteria, bacterial spores and viruses effectively ${ }^{15,39}$. The bactericidal effectiveness of aqueous chlorine dioxide against bacteria on the surface of lettuce, cabbage, cucumber, and green pepper has been reported ${ }^{17,46,56}$. Chlorine dioxide $\left(\mathrm{ClO}_{2}\right)$ is much more soluble than chlorine in water and has about 2.5 times higher oxidizing capacity than hypochlorous acid $(\mathrm{HOCl})^{3}$. Chlorine dioxide does not form chlorinated organic compounds to the extent observed with chlorine. ASC, an antimicrobial agent, is prepared from mixing sodium chlorite $\left(\mathrm{NaClO}_{2}\right)$ solution with a generally-recognized-as-safe (GRAS) organic acid. This chemical reaction produces active chlorine dioxide that shows bactericidal activity in combination with acidity. The U.S. Food and Drug Administration approved ASC for use in poultry, red meat, comminuted meat products, and processed fruits and vegetables to reduce bacterial contamination $^{54}$. Application of the bactericidal effect of 
ASC for surface washing of raw salmon ${ }^{52}$, beef carcass ${ }^{11}$, and broiler carcasse ${ }^{26}$ has been studied. However, only a few studies have been performed to apply the bactericidal effect of ASC for the surface washing of raw vegetables or fruits ${ }^{18,34}$. We constructed a sensitive detection system for injured bacteria ${ }^{20}$ and evaluated the effectiveness of ASC in killing E. coli $\mathrm{O} 157: \mathrm{H} 7$ on leafy vegetables with a view to its potential application to foods and food contact surfaces as an anti-microbial treatment ${ }^{22}$.

Chinese cabbages were cut into $3 \times 3 \mathrm{~cm}$ pieces and $400 \mathrm{~g}$ of leaf pieces were dipped into 1,200 $\mathrm{mL}$ of an inoculum cocktail containing four E. coli O157:H7 strains. After gently mixing for $10 \mathrm{~min}$, inoculated leaves were placed on a sterile perforated tray and dried at room temperature for $30 \mathrm{~min}$. One hundred grams of inoculated leaves were mixed with $1,000 \mathrm{~mL}$ of the wash solution containing sodium chlorite, organic acids or other chemical compounds in a stainless container. Inoculated leaves were treated in wash solution for $15 \mathrm{~min}$ at room temperature with a glass rod used for gentle mixing. In our work with cabbage leaves sodium chlorite showed lower bactericidal effect, but in combination with citric acid resulted in approximately a $3 \log \mathrm{CFU} / \mathrm{g}$ reduction of the population (Fig. 2). There was no significant difference in the sanitation efficacy among different organic acid (citric acid, succinic acid, malic acid, tartaric acid, acetic acid, lactic acid, and propionic acid) activated- acidified sodium chlorite (ASC) solutions (Fig. 3). Sanitation efficacy of ASC with mild heat treatment $\left(50^{\circ} \mathrm{C}\right)$ significantly increased (4.0 $\log \mathrm{CFU} / \mathrm{g})$ the population reduc-

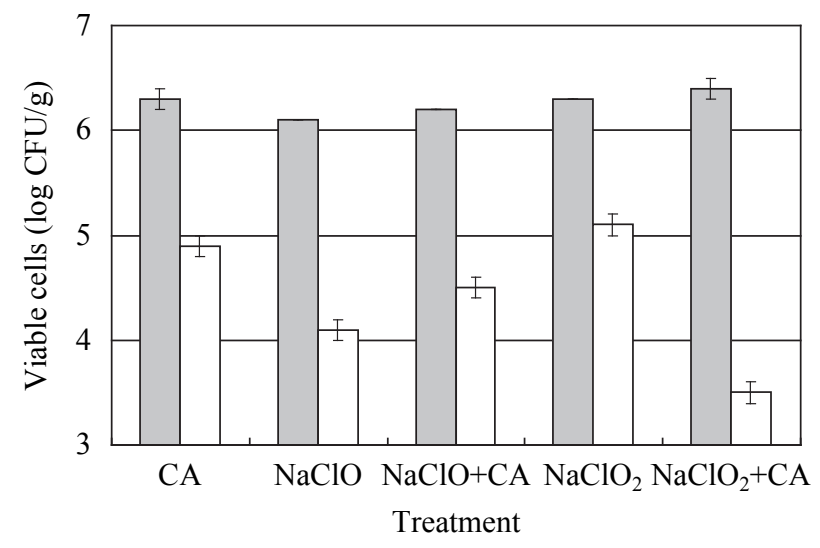

Fig. 2. Comparison of the bactericidal effect among several washing solutions

Precut Chinese cabbage leaves were washed for 15 minutes at room temperature. Value are mean \pm standard deviation $(\mathrm{n}=4)$. CA: Citric acid $(1 \mathrm{~g} / \mathrm{L})$, NaClO: Sodium hypochlorite (100 ppm as $\left.\mathrm{Cl}_{2}\right)$, $\mathrm{NaClO}_{2}$ : Sodium chlorite $(0.5 \mathrm{~g} / \mathrm{L})$. The symbols $\square$ and $\square$ correspond to the viable cell counts of the samples before and after washing, respectively. tion compared to that of treatment at room temperature or $4^{\circ} \mathrm{C}$, both of which showed a similar reduction of 2.5 $\log$ CFU/g of E. coli O157:H7 (Fig. 4). The color of the leaves was not affected by the temperature treatments, but

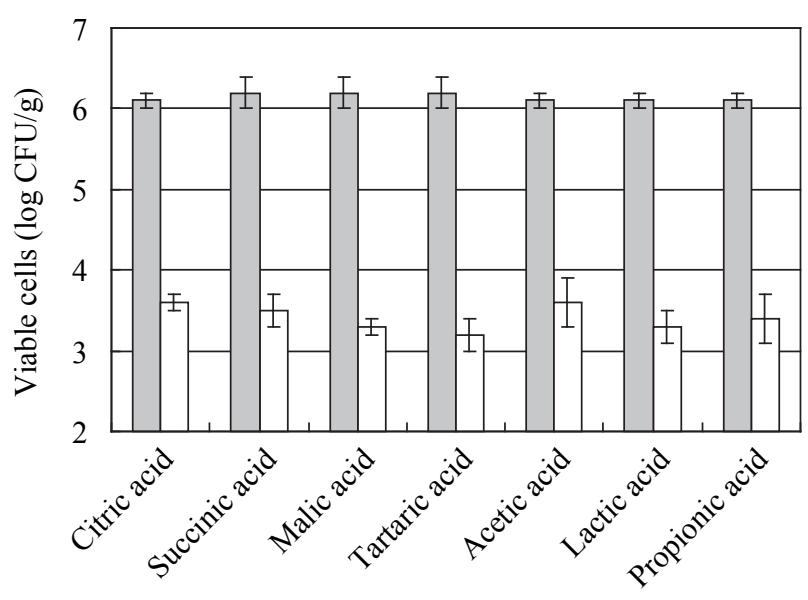

Acids used for ASC preparation

Fig. 3. Efficiency of population reduction of various organic acids coupling with sodium chlorite

$5 \mathrm{mM}$ of the indicated organic acid and $0.5 \mathrm{~g} / \mathrm{L}$ of sodium chlorite were used for washing. Experimental conditions are the same as Fig. 2. Values are mean \pm standard deviation $(n=4)$. The symbols $\square$ and $\square$ correspond to the viable cell counts of the samples before and after washing, respectively.

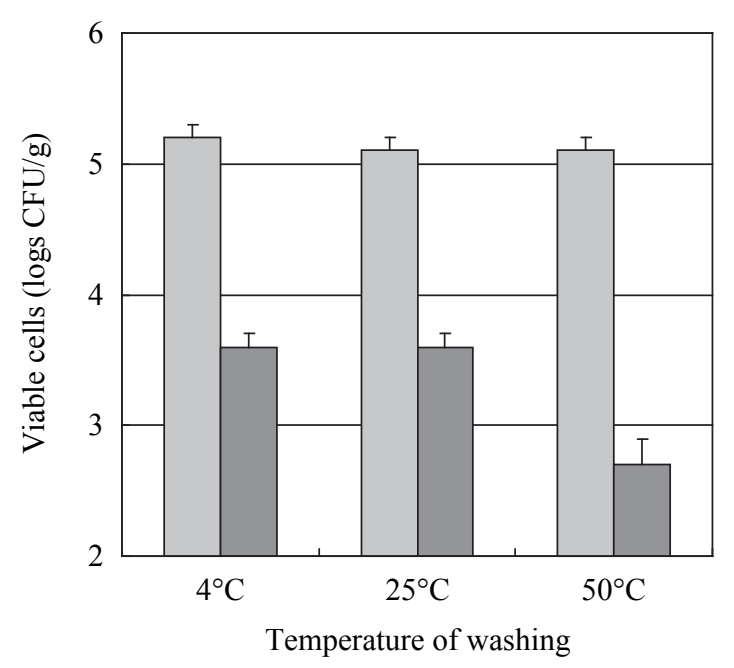

Fig. 4. Efficiency of population reduction with sodium chlorite and citric acid at various temperatures

$0.5 \mathrm{~g} / \mathrm{L}$ of sodium chlorite and $1 \mathrm{~g} / \mathrm{L}$ of citric acid was used for 15 minutes washing. Experimental conditions are the same as Fig. 2 except for the temperature during washing. Values are mean \pm standard deviation ( $\mathrm{n}=4)$. The symbols $\square$ and $\square$ correspond to the viable cell counts of the water washed or ASC washed samples, respectively. 
the texture was apparently softened at $50^{\circ} \mathrm{C}$.

Although sodium chlorite solutions have been reported to possess a strong antibacterial effect, antibacterial activity can be greatly reduced by the presence of organic matter ${ }^{36}$. The addition of organic or inorganic acids to acidify sodium chlorite results in an increased antibacterial capacity of this compound. The antibacterial activity of ASC is attributed to the oxidative effect of chlorous acids, which are derived from the conversion of chlorite ion into its acid form under acidic conditions ${ }^{16}$. If the acidification of sodium chlorite is not controlled, other antimicrobial compounds, such as chlorine dioxide, may also be produced as a result of rapid chlorite disproportionation $^{53}$. In our work, all concentrations and acidity conditions were selected so that chlorite ions underwent several disproportionation reactions, producing secondary bactericidal oxidative compounds, mainly oxychlorines, as well as more chlorous acid and small amounts of chlorine dioxide ${ }^{16}$. As chlorous acid is being depleted, residual chlorite produces more chlorous acid, which will augment the series of reactions and the antibacterial effect continues until evaporation and drying of the solution on the surface of leaves. These reactions occur instantaneously on mixing, and therefore the antibacterial solutions need to be prepared shortly before use.

\section{Application of ASC prewashing for lightly fermented vegetable production}

Chinese cabbage is commonly used for the production of lightly fermented vegetables, a very popular foodstuff in Japan. Such lightly fermented foods are consumed within 2 days of preparation. In this study, prewashed cabbage with ASC was applied for the production of these fermented products ${ }^{23}$. This time, we examined 4 kinds of pathogenic bacteria; Escherichia coli 0157 : H7, Salmonella Enteritidis, Staphylococcus aureus, and Listeria monocytogenes. At least 4 strains of the cultures were mixed and used for inoculation similar to that described above. Five hundred grams of inoculated leaves were mixed with $5.0 \mathrm{~L}$ of the ASC solution containing sodium chlorite $(0.5 \mathrm{~g} / \mathrm{L})$ and citric acid $(1.0 \mathrm{~g} / \mathrm{L})$ in a container. Sterile distilled water was used for control experiments. Washing treatment was for $15 \mathrm{~min}$ at room temperature with a glass rod used for gentle agitation. After removing the residual ASC by washing with sterile distilled water, the leaf pieces were soaked with dry salt $(30 \mathrm{~g} / \mathrm{kg})$ and then $7 \%$ sodium chloride water $(300 \mathrm{~mL} /$ $\mathrm{kg}$ ) was added and kept at $10^{\circ} \mathrm{C}$ for 8 days under pressure $\left(20 \mathrm{~g} / \mathrm{cm}^{2}\right)$ for salt curing. Microbiological analyses were performed each day. After 2 days of fermentation, the lactic acid concentration was recorded as $33.3 \pm 8.5 \mu \mathrm{g} / \mathrm{g}$ - sample and the $\mathrm{pH}$ was recorded as $5.67 \pm 0.07$, for ASC washed cabbage. Whereas in the treatment using distilled water to wash cabbage, the lactic acid concentration and $\mathrm{pH}$ were $33.4 \pm 0.7 \mu \mathrm{g} / \mathrm{g}$-sample and $5.63 \pm 0.17$, respectively. However, no pathogenic bacteria were detected before or after fermentation in any of the Chinese cabbage tested. The aerobic plate counts for unwashed cabbage samples were approximately $6.39 \log \mathrm{CFU} / \mathrm{g}$ and a distilled water wash could reduce this by approximately 0.6 $\log \mathrm{CFU} / \mathrm{g}$, however, the population increased with incubation time. Washing the sample with ASC could reduce the population by approximately $2.0 \log \mathrm{CFU} / \mathrm{g}$ and that remained relatively constant for up to 2 days and thereafter increased gradually with the incubation period (Fig. 5). A similar increase of aerobic mesophilic bacteria after surface sanitation of leafy vegetables was observed ${ }^{29}$. This may be caused by the wet condition and nutrient supply from partially injured vegetable leaf surfaces. The sanitation efficacy is thought to be lost naturally during storage or removed by secondary washing with water. Additional ways to control bacteria such as the use of food additives will be required in some cases.

Various microorganisms, including the lactic acid bacteria are naturally present in the Chinese cabbage. However, the growth, activity, and role of the microorganisms participating in the fermentation are influenced by several factors, including salt concentration, temperature, $\mathrm{pH}$, population of related microorganisms, and exposure to air ${ }^{12}$. Lightly fermented cabbage is usually held for only a short time at $10^{\circ} \mathrm{C}$ and consumed before further fermentation occurs. Therefore, this condition might not be suitable for the growth of some undesirable bacteria that could spoil the product. This may be the reason for the growth of aerobic bacteria in this fermentation pro-

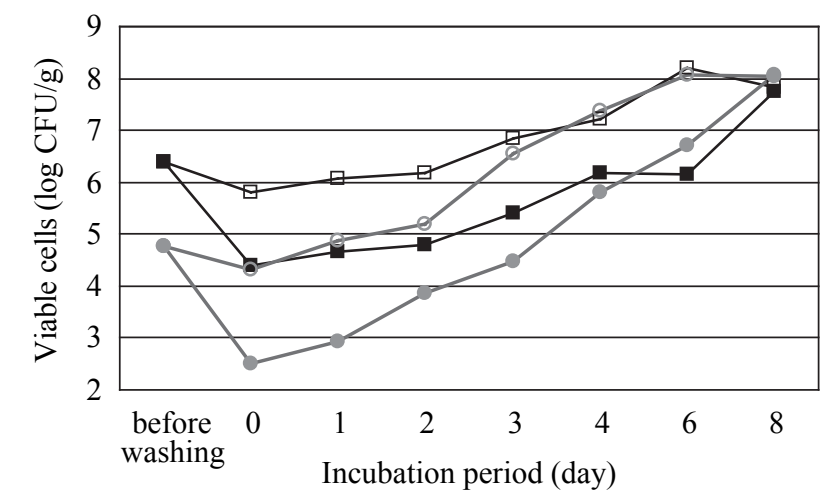

Fig. 5. The total plate count $(\square)$ and coliforms $(O)$ of Chinese cabbage before and after being water (open symbol) or ASC (closed symbol) washed and incubated at $10^{\circ} \mathrm{C}$ with $3 \%$ salt for fermentation for 8 days 
cess. Moreover, Cheigh et al. ${ }^{12}$ reported that the aerobic bacterial count increased for up to 20 days and after that, decreased gradually with the days of incubation.

Chinese cabbage dip inoculated with a cocktail of $E$. coli $\mathrm{O} 157: \mathrm{H} 7$ or Salmonella $(7.1 \log \mathrm{CFU} / \mathrm{mL})$ resulted in 6.3 or $6.7 \log \mathrm{CFU} / \mathrm{g}$, respectively, on the surface of the leaves. Washing leaves with distilled water reduced the population by less than $1.0 \log \mathrm{CFU} / \mathrm{g}$ and that remained constant throughout the incubation period (Fig. 6). However, treatment with ASC reduced the population by more than $2.0 \log \mathrm{CFU} / \mathrm{g}$ and that remained relatively constant throughout the incubation period. Salmonella increased gradually up to day 4 followed by a slight decrease in population by day 8 .

Similarly in the case of Staphylococcus aureus, washing with distilled water and ASC reduced the population by $<1.0 \log \mathrm{CFU} / \mathrm{g}$ and $2.4 \log \mathrm{CFU} / \mathrm{g}$, respectively. The populations remained relatively constant throughout the incubation period. ASC reduced the population of $L$. monocytogenes by $2.2 \log \mathrm{CFU} / \mathrm{g}$ from its initial population level (6.4 log CFU/g); however, the population increased with incubation time. As shown in Fig. 6, the population increased gradually and reached to the maximum level of $7.0 \mathrm{log}$ CFU/g by the 8th day of incubation.

The quality of treated and untreated uninoculated salted Chinese cabbage was evaluated by a panel consisting of 27 sensory experts ( 17 female and 10 male) selected from different departments of the National Food Research Institute. No significant influence on the color,

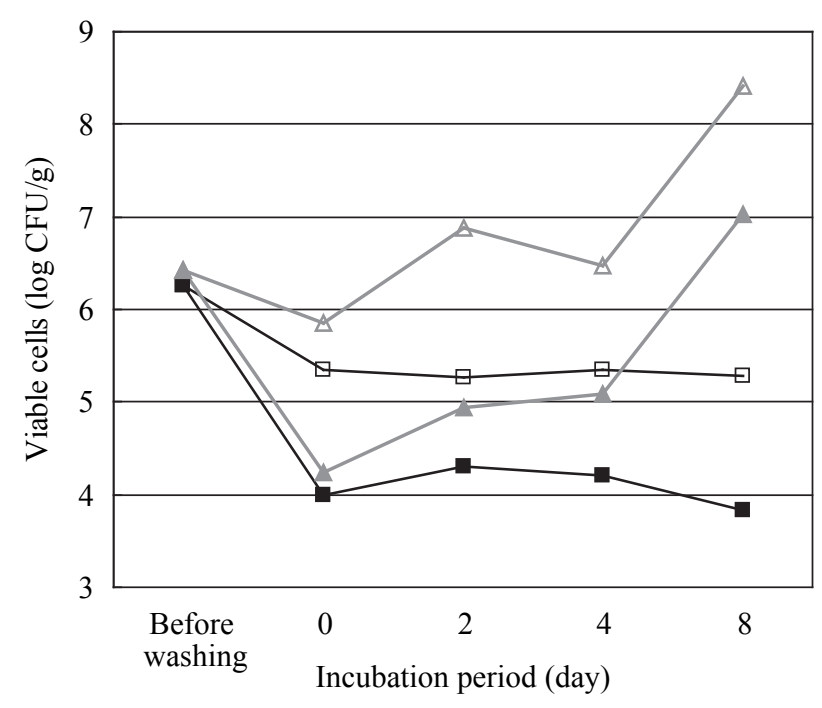

Fig. 6. Population of E. coli O157:H7 ( $\square$ ) or $L$. monocytogenes $(\triangle)$ recovered from Chinese cabbage before and after being water (open symbol) or ASC (closed symbol) washed and incubated at $10^{\circ} \mathrm{C}$ with $\mathbf{3} \%$ salt for fermentation for 8 days odor, taste, and texture was observed after treatment with acidified sodium chloride. The sensory evaluation was done after 2 days of fermentation since these products are usually consumed within this time frame ${ }^{27}$. However, several research reports showed that there are no significant changes in appearance, color, odor, taste, and texture after 4 days of fermentation ${ }^{28,54}$.

\section{Conclusion and perspective}

Chinese cabbage or other leafy vegetables are usually grown at 20 to $30^{\circ} \mathrm{C}$ in soil ${ }^{47}$ and therefore contamination of these vegetables can come from various sources, including polluted soil, animal manure, irrigation water, contaminated water and equipment in the processing plant, filthy transport vehicles and containers, and unhygienic food plant workers. Once contaminated, the bacterial population can increase during storage at temperatures higher than the refrigeration temperature $\left(10^{\circ} \mathrm{C}\right)$ even after the addition of salt. Therefore, prewashing with sanitizer could reduce the potential risk associated with these vegetables or vegetable products such as lightly fermented vegetables. These kinds of foods were commonly produced not only in Japan but also Korea, Thailand, Viet Nam, and other (South) East Asian countries. In this study, we evaluated the effectiveness of ASC for prewashing of Chinese cabbage for lightly fermented vegetables. However, a large-scale series of experiments using this method must be done to determine the reproducibility of the results obtained in these studies reported here.

Some residual bacteria including pathogenic bacteria such as Listeria monocytogenes and some spoilage bacteria after prewashing with ASC or chlorinated water can grow during $10^{\circ} \mathrm{C}$ storage under $3 \%$ salted condition. The addition of natural antimicrobial compounds into the final products may partially reduce the risk of food poisoning or quality loss associated with the growth of the bacteria ${ }^{13,24,48}$. In addition, transportation and storage of the products should be under suitable conditions. The development of cheap, safe and convenient integrated temperature indicators would be required for the management of increasing microbial risk during the cold storage and distribution process.

\section{Acknowledgments}

This work was supported by a grant-in-aid (Integrated Research Program for Functionality and Safety of Food toward an Establishment of Healthy Diet) from the Ministry of Agriculture, Forestry and Fisheries of Japan. 


\section{References}

1. Adams, M. R. \& Nicolaides, L. (1997) Review of the sensitivity of different foodborne pathogens to fermentation. Food Control, 8, 227-239.

2. Anonymous (2003) An outbreak of EHEC O157:H- infection at a nursery school suspected to be caused by lightly salted cucumbers, June-July 2002 - Fukuoka City. Infect. Agents Surv. Rep., 24, 132-133.

3. Benarde, M. A. et al. (1965) Efficiency of chlorine dioxide as a bactericide. Appl. Microbiol., 13, 776-780.

4. Beuchat, L. R., Ward, T. E. \& Pettigrew, C. A. (2001) Comparison of chlorine and a prototype produce wash product for effectiveness in killing Salmonella and Escherichia coli $\mathrm{O} 157: \mathrm{H} 7$ on alfalfa seeds. J. Food. Prot., 64, 152-158.

5. Beuchat, L. R. (1992) Surface disinfection of raw produce. Dairy Food Environ. Sanit., 12, 6-9.

6. Beuchat, L. R. (1996) Pathogenic microorganisms associated with fresh produce. J. Food Prot., 59, 204-216.

7. Beuchat, L. R. (1998) Surface decontamination of fruits and vegetables eaten raw: a review. Food Safety Unit, World Health Organization.WHO/FSF/FOS/98.2, pp. 42. Available online at http://www.who.int/foodsafety/publications/fs_management/en/surface_decon.pdf.

8. Beuchat, $\bar{L}$. R. et al. (2001) Development of a proposed standard method for assessing the efficacy of fresh produce sanitizers. J. Food Prot., 64, 1103-1109.

9. Brackett, R. E. (1992) Shelf stability and safety of fresh produce as influenced by sanitation and disinfections. $J$. Food. Prot., 55, 808-814.

10. Buckenhuuskes, H. J. (2001) Fermented vegetables. In Food microbiology: fundamentals and frontiers, 2nd edition, ed. Doyle, M. P., ASM Press, Washington D.C., 665679.

11. Castillo, A. et al. (1999) Reduction of Escherichia coli O157:H7 and Salmonella typhimurium on beef carcass surfaces using acidified sodium chlorite. J. Food Prot., 62, 580-584.

12. Cheigh, H. -S. \& Park, K. -Y. (1994) Biochemical, microbiological, and nutritional aspects of Kimchi (Korean fermented vegetable products). Crit. Rev. Food Sci. Nutrient., 34, 175-203.

13. Choi, M. H. \& Park, Y. H. (2000) Selective control of lactobacilli in kimchi with nisin. Lett. Appl. Microbiol., 30, 173-177.

14. Daeschel, M. A., Andersson, R. E. \& Fleming, H. P. (1987) Microbial ecology of fermenting plant materials. FEMS Microbiol. Rev., 46, 357-367.

15. Foegeding, P. M., Hemstapat, V. \& Giesbrecht, F. G. (1986) Chlorine dioxide inactivation of Bacillus and Clostridium spores. J. Food Sci., 51, 197-201.

16. Gordon, G. et al. (1972) The chemistry of chlorine dioxide. In Progress in inorganic chemistry, vol. 15, ed., Lippard, S. J., Wiley-Interscience, New York, 201-286.

17. Han, Y. et al. (2001) Reduction of Listeria monocytogenes on green peppers (Capsicum annuum L.) by gaseous and aqueous chlorine dioxide and water washing and its growth at $70^{\circ} \mathrm{C}$. J. Food Prot., 64, 1730-1738.

18. Hasegawa, Y. et al. (1990) Comparison between the effects of sodium chlorite and sodium hypochlorite on the freshness of fish and vegetable. J. Food Hyg. Soc. Jpn., 31, 261-265 [In Japanese with English summary].

19. Hidaka, T. et al. (1992) Disappearance of residual chlorine and formation of chloroform in vegetables treated with sodium hypochlorite. J. Food Hyg. Soc. Jpn., 33, 267-273 [In Japanese with English summary].

20. Inatsu, Y. et al. (2003) Construction and validation of antibiotic resistance Escherichia coli strains for acidic foods. Jpn. J. Food Microbiol., 20, 177-183.

21. Inatsu, Y. et al. (2004) Survival of Escherichia coli O157: H7, Salmonella Enteritidis, Staphylococcus aureus, and Listeria monocytogenes in Kimchi. J. Food Prot., 67, 1497-1500.

22. Inatsu, Y. et al. (2005a) Efficacy of acidified sodium chlorite treatments in reducing Escherichia coli $\mathrm{O} 157: \mathrm{H} 7$ on Chinese cabbage. J. Food Prot., 68, 251-255.

23. Inatsu, Y. et al. (2005b) Prewashing with acidified sodium chlorite reduces pathogenic bacteria in lightly fermented Chinese cabbage. J. Food Prot., 68, 999-1004.

24. Inatsu, Y. et al. (2005c) Effectiveness of some natural antimicrobial compounds in controlling pathogen or spoilage bacteria in lightly fermented Chinese cabbage. J. Food Sci., 70(9), M393-M397.

25. Kadowaki, M. et al. (1988) Study of the shelf life of lightly fermented Chinese cabbage from the aspect of contaminated bacterial growth. Research report of IAI Center for Food Quality, Labeling and Consumer Services, 12, $77-82$.

26. Kemp, G. K., Aldrich, M. L. \& Waldroup, A. L. (2000) Acidified sodium chlorite antimicrobial treatment of broiler carcasses. J. Food Prot., 63, 1087-1092.

27. Koseki, S. et al. (2004) Efficacy of acidic electrolyzed water for microbial decontamination of cucumbers and strawberries. J. Food Prot., 67, 1247-1251.

28. Koseki, S. et al. (2004) Effect of mild heat pre-treatment with alkaline electrolyzed water on the efficacy of acidic electrolyzed water against Escherichia coli $\mathrm{O} 157: \mathrm{H} 7$ and Salmonella on lettuce. Food Microbiol., 21, 559-566.

29. Koseki, S. \& Isobe, S. (2006) Effect of ozonated water treatment on microbial control and on browning of iceberg lettuce (Lactuca sativa L.). J. Food Prot., 69, 154-160.

30. Lang, M. M., Ingham, B. H. \& Ingham, S. C. (2000) Efficacy of novel organic acid and hypochlorite treatments for eliminating Escherichia coli O157:H7 from alfalfa seeds prior to sprouting. Int. J. Food Microbiol., 58, 73-82.

31. Lee, C. -H. (1997) Lactic acid fermented foods and their benefits in Asia. Food Control, 8, 259-269.

32. Li, Y. et al. (2001) Survival and growth of Escherichia coli $\mathrm{O} 157: \mathrm{H} 7$ inoculated onto cut lettuce before or after heating in chlorinated water, followed by storage at 5 or $15^{\circ}$ C. J. Food Prot., 64, 305-309.

33. Lillard, H. S. (1979) Levels of chlorine and chlorine dioxide of equivalent bactericidal effect in poultry processing water. J. Food Sci., 44, 1594-1597.

34. Lukasik, J. et al. (2003) Reduction of poliovirus 1, bacteriophages, Salmonella Montevideo, and Escherichia coli O157:H7 on strawberries by physical and disinfectant washes. J. Food Prot., 66, 188-193

35. Miyao, S. (1997) Microbiological controlling of fermented vegetables. Nihon shokuhin kagaku kougaku kaishi (J. Jpn. Soc. Food Sci. Tech.), 44, 1-9 [In Japanese]. 
36. Mullerat, J., Sheldon, B. W. \& Klapes, N. A. (1995) Inactivation of Salmonella species and other food-borne pathogens with Salamides ${ }^{\circledR}$, a sodium chlorite-based oxyhalogen disinfectant. J. Food Prot., 58, 535-540.

37. National Advisory Committee on Microbiological Criteria for Foods (1999) Microbiological safety evaluations and recommendations on fresh produce. Food Control, 10, 117-143.

38. Nguyen-the, C. \& Carlin, F. (1994) The microbiology of minimally processed fresh fruits and vegetables. Crit. Rev. Food Sci. Nutrit., 34, 371-401.

39. Noss, C. I. \& Olivieri, V. P. (1985) Disinfecting capabilities of oxychlorine compounds. Appl. Env. Microbiol., 50, 1162-1164.

40. Oosawa, J. et al. (1988) Quality control of lightly fermented vegetable by bacteriological regulation report. Iwateken jouzou shokuhin shikenjou houkoku (Iwate Pref. Res. Inst. Brew Food), 22, 7-12 [In Japanese].

41. O'Sullivan, L., Ross, R. P. \& Hill, C. (2002) Potential of bacteriocin-producing lactic acid bacteria for improvements in food safety and quality. Biochemie, 84, 593603.

42. Ozaki, N. et al. (2003a) A diffuse outbreak of enterohemorrhagic Escherichia coli O157:H- infection, probably caused by pickled cucumbers. Ann. Rep. Fukuoka. Health. Env. Res. Inst., 28, 120-128.

43. Ozaki, Y. et al. (2003b) A diffused outbreak of enterohemorrhagic Escherichia coli $\mathrm{O} 157: \mathrm{H} 7$ related to the Japanese-style pickles in Saitama, Japan. J. Jpn. Assoc. Infect. Dis., 77, 493-498.

44. Pederson, C. S. \& Albury, M. N. (1953) Factors affecting the bacterial flora in fermenting vegetables. Food Res., 18, 290-300.

45. Pederson, C. S. \& Albury, M. N. (1954) The influence of salt and temperature on the microflora of sauerkraut fermentation. Food Technol., 8(1), 1-5.
46. Reina, L. D., Fleming, H. P. \& Humphries, E. G. (1995) Microbiological control of cucumber hydrocooling water with chlorine dioxide. J. Food Prot., 58, 541-546.

47. Rubatzsky, V. E. \& Yamaguchi, M. (1997) World vegetables; principals, production and nutritive values, $2 \mathrm{nd}$ edition. Chapman \& Hill, New York, 365-463.

48. Savard, T. et al. (2002) Antimicrobial action of hydrolyzed chitosan against spoilage yeasts and lactic acid bacteria of fermented vegetables. J. Food Prot., 65, 828-833.

49. Singh, N. et al. (2002) Effect of inoculation and washing methods on the efficacy of different sanitizers against Escherichia coli 0157:H7 on lettuce. Food Microbiol., 19, 183-193.

50. Stamer, J. R., Stoyla, B. O. \& Dunckel, B. A. (1971) Growth rates and fermentation patterns of lactic acid bacteria associated with the sauerkraut fermentation. J. Milk Food Technol., 34, 521-525.

51. Steinkraus, K. H. (2000) Fermentations in world food processing. Comp. Rev. Food Sci. Food Safety, 1, 23-32.

52. Su, Y. -C. \& Morrissey, M. T. (2003) Reducing levels of Listeria monocytogenes contamination on raw salmon with acidified sodium chlorite. J. Food Prot., 66, 812818.

53. Thielemann, H. (1977) Chlorine dioxide in water treatment - monitoring and analysis. Zeitschrift Gesamte Hyg. Grenzgebiete, 23, 904-905.

54. U.S. Government Printing Office (1999) Acidified sodium chlorite solutions (21CFR 173.325). Code of Federal Regulations, Office of the Federal Register. Available online at http://www.gpoaccess.gov/cfr/retrieve.html.

55. Wei, C. -I., Cook, D. L. \& Kirk, J. R. (1985) Use of chlorine compounds in the food industry. Food Technol., 39(1), 107-115.

56. Zhang, S. \& Farber, J. M. (1996) The effects of various disinfectants against Listeria monocytogenes on fresh-cut vegetables. Food Microbiol., 13, 311-321. 